Service Life Prediction Methodology and Metrologies, ACS Symposium Series 805, Jonathan W Martin and David R. Bauer, Eds., American Chemical Society, 2002, pp 23-36.

\title{
Surface Moisture and Time of Wetness Measurements
}

\author{
Peter Norberg ${ }^{1}$ \\ Centre for Built Environment, \\ Royal Institute of Technology, Gävle, Sweden \\ ${ }^{1}$ Current address: Centre for Built Environment, \\ University of Gävle, Gävle, Sweden
}

\begin{abstract}
Surface moisture plays an important role in the deterioration of building surfaces. The extent and duration of surface moisture is generally impossible to predict from meteorological data. The limitations of the ISO 9223 standard for estimating the time of wetness (TOW; $\mathrm{RH}>80 \%, \mathrm{~T}>0^{\circ} \mathrm{C}$ ) is evident in climates with sub-zero temperatures, in environments with significant deposition of pollutants and salt, and in situations where the exchange of radiation between building surfaces and the surrounding environment creates large temperature differences. Consequently, direct measurement of TOW is essential, e.g. using the WETCORR method. This method is suitable for measurements of surface moisture and TOW on building materials in general. The actual sensor consists of an inert electrolytic cell with $\mathrm{Au} / \mathrm{Au}$-electrodes combined with a Pt-1000 surface temperature-sensing element
\end{abstract}

\section{Background}

The interest in surface moisture and time of wetness (TOW) has its origin in the field of atmospheric corrosion. Early on, Vernon (1) had shown that the corrosion rate of steel increased dramatically when a critical relative humidity (RH) of between 80 and $90 \%$ was exceeded. Understanding of the various mechanisms that, even under non-condensing conditions, can result in the build-up of significant amounts of moisture on metallic surfaces, and thereby cause corrosion, was essential for the continued research in this area. In addition, the electrochemical nature of the typical moist or wet atmospheric corrosion became more and more obvious (2). This also led to the adoption of electrochemical methods for study- 


\section{Service Life Prediction Methodology and Metrologies, ACS Symposium Series 805, Jonathan W Martin and David R. Bauer, Eds., American Chemical Society, 2002, pp 23-36.}

ing the instantaneous rate of atmospheric corrosion with the prospects of replacing the traditional and time-consuming weight loss measurements done by longterm exposures of test coupons.

Mansfeld $(3,4)$ has reviewed the early experience of electrochemical measurements of atmospheric corrosion and its relation to the concept of TOW. In this context TOW is commonly considered as the time for which the atmospheric conditions are such that electrochemical reactions of some magnitude can occur on the surface of the sensor. There is a general opinion among atmospheric corrosion scientists that surface moisture and TOW play a very important role in the corrosion of metals and alloys exposed to the atmosphere. Consequently, the idea of a critical RH determining TOW is very much reflected in the current standard ISO 9223 (5) defining TOW as the time for which RH is greater than $80 \%$ while the air temperature is above $0^{\circ} \mathrm{C}$. As has been shown by many investigators this meteorological approach has its limitations, partly because the electrochemical reactions are in operation far below $0^{\circ} \mathrm{C}(6,7,8)$. It is also well known that the presence of hygroscopic salts on the surface $(2,4)$ can considerably lower the humidity where wetting occurs. In addition, the difference between air and surface temperatures, as governed by the radiation conditions, is a very important factor to consider in relation to TOW $(6,9,10)$.

In the very first attempt to study atmospheric corrosion by electrochemical methods, Tomashov and co-workers $(2,11)$ used galvanic cells with alternate electrodes of different metals, e.g. $\mathrm{Fe} / \mathrm{Cu}, \mathrm{Fe} / \mathrm{Zn}, \mathrm{Fe} / \mathrm{Al}$ and $\mathrm{Cu} / \mathrm{Al}$. When a film of moisture appeared on the surface of the electrode lamellae, a potential difference was produced between the terminals and the resulting external current was measured with a sensitive galvanometer. Sereda $(12,13)$ used galvanic cells of the types $\mathrm{Pt} / \mathrm{Fe}$ and $\mathrm{Pt} / \mathrm{Zn}$ but measured the variation in voltage across an external resistor through which the galvanic current was flowing. TOW in these cases was defined as the time during which the galvanic current or voltage exceeded an arbitrary thres-hold value. Sereda et al (6) also made way for the ASTM standard (14) covering that particular method for the electrode combinations $\mathrm{Au} / \mathrm{Cu}$, $\mathrm{Au} / \mathrm{Zn}$ and Pt/Ag. More recently, Hechler et al (7) have studied exposures of large sets of sensors following the ASTM procedure.

Kucera and Mattsson (15) and Mansfeld and co-workers $(3,4,16,17)$ adopted the original concept of Tomashov using $\mathrm{Cu} / \mathrm{steel}$ or $\mathrm{Cu} / \mathrm{Zn}$ couples and studied the galvanic current, trying to relate this to the rate of atmospheric corrosion. Kucera and co-workers $(15,18)$ and Mansfeld and co-workers $(3,4,16,17,19)$ also used electrolytic cells of only one metal, e.g. $\mathrm{Cu} / \mathrm{Cu}$, steel/steel and $\mathrm{Zn} / \mathrm{Zn}$, to which an external constant voltage was applied. Kucera used voltages in the range $100-400 \mathrm{mV}$ and the resulting current was only a vague measure of the corrosion rate, while Mansfeld limited the potential difference to $\pm 30 \mathrm{mV}$ in order to enable measurement of the corrosion current on the basis of the polarisation resistance technique.

The development of the electrolytic method originally proposed by Kucera and Mattsson (15) has continued in Scandinavia during the past 20-25 years, to a large extent within the frames of joint Nordic research programmes involving the Swedish Corrosion Institute (SCI) and the Norwegian Institute for Air Research (NILU), e.g. Haagenrud et al (20). Further efforts made by NILU led to the socalled NILU WETCORR (WETness and COrrosion Rate Recorder) method, involving an automatic six-channel current integrator and the use of miniature $\mathrm{Cu} / \mathrm{Cu}$ cells, Haagenrud et al (21). A theoretical study of the electrochemical 


\section{Service Life Prediction Methodology and Metrologies, ACS Symposium Series 805, Jonathan W Martin and David R. Bauer, Eds., American Chemical Society, 2002, pp 23-36.}

characteristics of the NILU/SCI sensor was done by Haagenrud et al (22) who showed, among other things, how the recorded current was depending on the thickness of the deposited moisture film.

More recent collaboration between NILU and the National Swedish Institute for Building Research (SIB) aimed at extending the NILU WETCORR concept to mea-surements of surface moisture and TOW on building materials and structures in general, Haagenrud et al (23) and Svennerstedt $(24,25)$. The surface moisture studies by Lindberg (26) on paint and Yamasaki (27) on plastics should also be mentioned in this context as examples of TOW studies made on nonmetallic materials. This generalisation of the view on TOW should have implications not only for the definition of the TOW concept as such but also for the measurement technique and the sensors used.

In the following a brief overview will be given of the experience gained in relation to the development and use of the WETCORR method, as seen from a Scandinavian perspective.

\section{The WETCORR system}

The WETCORR measurement technique, the way it is done today, was first introduced by Haagenrud et al (21) in 1984. Since that time several versions of instrument and sensor have been in use in Scandinavia. In the following sections the present version of the WETCORR system will be outlined with some reference to older devices.

\section{Instrumentation}

The most recent version of the WETCORR system, which has been in use since late 1994, is very similar to the one used previously, a description of which was given by Norberg (28). An overview of the present system is shown in Figure 1. The WETCORR system can measure surface moisture and surface temperature from up to 64 sensors simultaneously. The actual measurements are conducted by up to 16 sensor adapters, each connecting a maximum of 4 sensors. The system controller communicates with the sensor adapters via an RS485network and also provides the necessary power. The basic principle of the measuring technique involves excitation of the sensor with a DC voltage of normally $100 \mathrm{mV}$. To avoid net polarisation of the electrodes in the long perspective the polarity is reversed every 30 seconds. The absolute value of the resulting current is averaged over one voltage cycle, i.e. one minute. The main difference between the previous version of WETCORR and the present is that the temperature channels now require Pt-1000-elements instead of AD592AN-transducers. This improvement makes it possible to more accurately measure temperature in general and surface temperature in particular. 


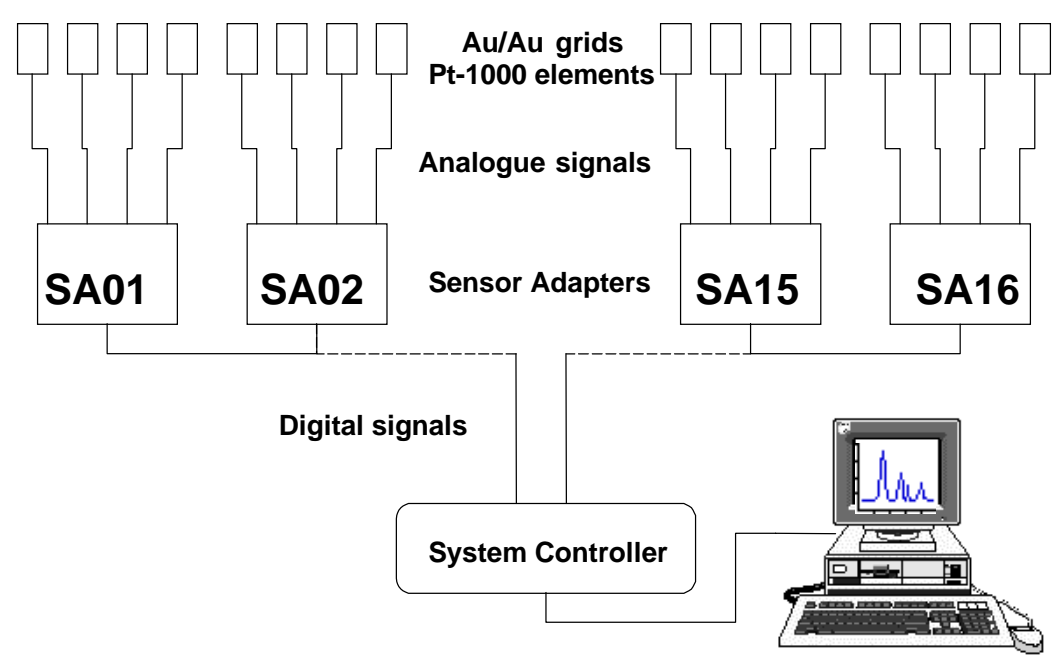

Figure 1. The WETCORR system

\section{Sensor design}

The present type of sensor is the third generation of the Au/Au-type of cell developed for the WETCORR system. The active grid measures 16 by $18 \mathrm{~mm}$ and the overall size is 22 by 30 by $0.7 \mathrm{~mm}$, see Figure 2 . The earlier generations of cell have been evaluated in $(28,29)$. The main improvements include a better design of the electrode pattern, which should minimise interference between the measurements of moisture and temperature. In addition, for surface temperature measurements a very small Pt-1000-element was chosen, showing much better temperature adaptability and tolerance than the previous version. Preliminary experience in severe marine atmospheres has also indicated that this sensor is better suited to cope with salt films on the surface. This sensor is the latest in use and is produced by the Kongsberg Group in Kjeller, Norway.

\section{Sensor characteristics}

Haagenrud et al (21) studied the influence of alternating DC voltage on $\mathrm{Cu} / \mathrm{Cu}$-cells and found that a 5-6-fold increase in integrated current resulted compared with excitation using constant DC voltage. The influence of polarity reversal on the current response at different RH-levels was demonstrated in detail in (29), and the principal response of the current on reversal of the voltage is shown in Figure 3. The capacitance character of the electrochemical double layer governs the transient response of the current, especially at high moisture loads. 
Service Life Prediction Methodology and Metrologies, ACS

Symposium Series 805, Jonathan W Martin and David R. Bauer, Eds., American Chemical Society, 2002, pp 23-36.

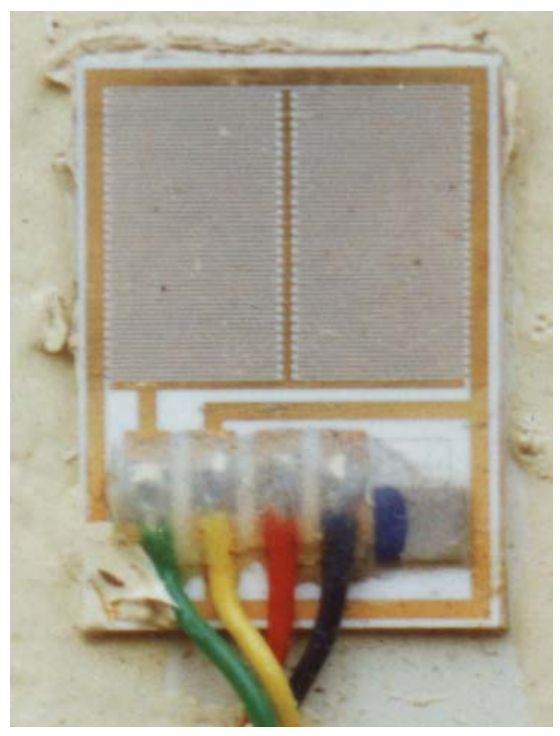

Figure 2. The latest WETCORR sensor.

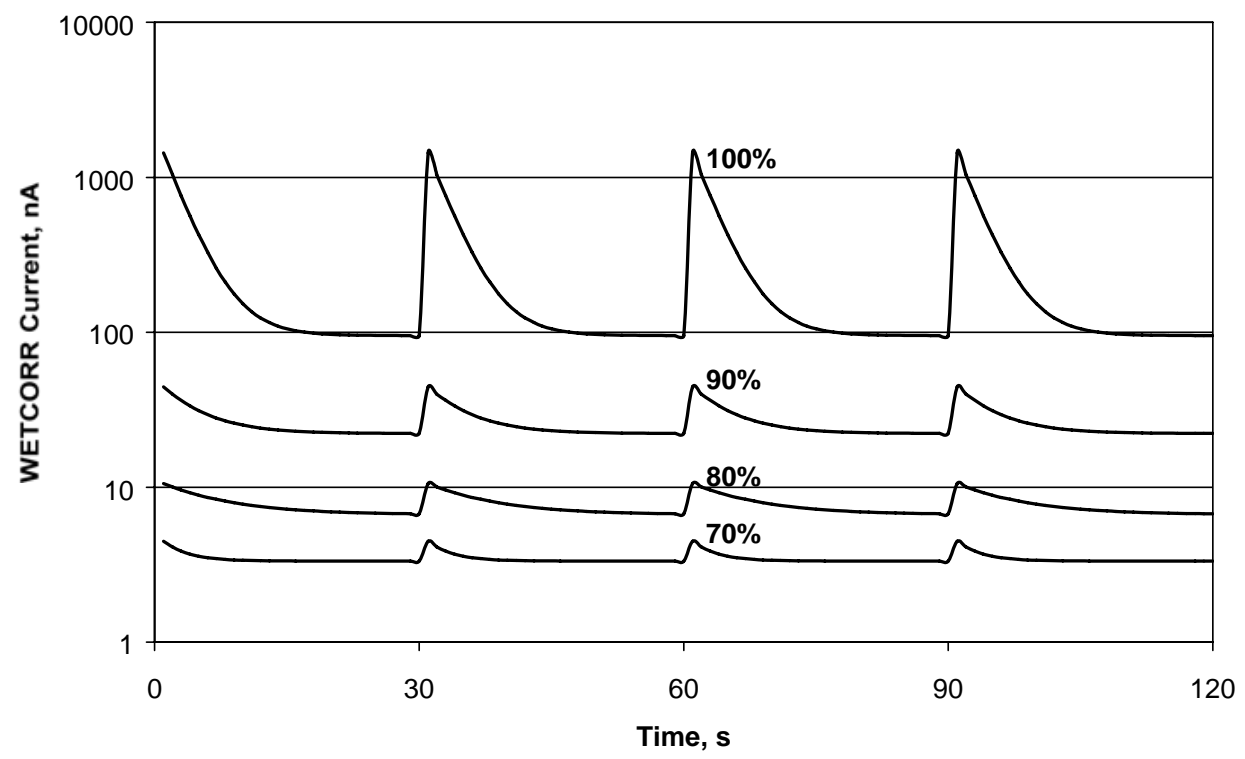

Figure 3. The response of the WETCORR current on polarity reversal at different relative humidities.

The principal shape of these curves and their relative appearance reveal that the TOW sensor, as a first approximation, may be described by an RC-circuit containing two resistors and one capacitor (30), see Figure 4. 


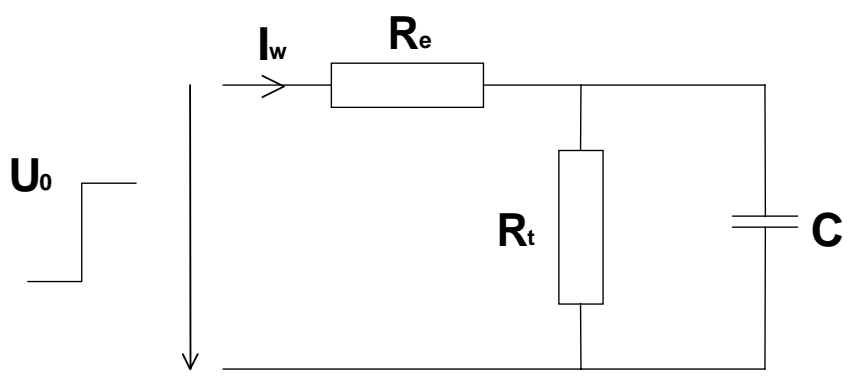

Figure 4. Equivalent electric circuit model for the WETCORR sensor.

$R_{e}$ is the resistance of the electrolyte between the electrode fingers, $R_{t}$ the resistance associated with the transfer of charges between the electrolyte and the electrode surface and $C$ the capacitance of the electrochemical double layer in the vicinity of the electrode surface. The time dependence of the WETCORR current $\mathrm{I}_{\mathrm{w}}$ after applying a step voltage $\mathrm{U}_{0}$ may be written as follows, using the notation in Figure 4.

$$
I_{w}=\frac{U_{0}}{R_{e}+R_{t}}\left(1+\frac{R_{t}}{R_{e}} e^{-\frac{R_{e}+R_{t}}{R_{e} R_{t} C}}\right)
$$

The validity of this equation was tried out in (31) and it was confirmed that a satisfactory agreement with the measured curves was obtained and that the simple electronic circuit could explain the main features of the curves.

From this it may be concluded that the current measured with the WETCORR method not only reflects the resistance of the electrolyte, $R_{e}$, but also the impedance associated with the processes occurring at the electrode surfaces following the polarisation. However, a generalised view on the concept of TOW should be related to $R_{e}$ rather than to the polarisation-induced impedance. This will be further discussed under the heading "Time of wetness".

\section{Experience from measurements}

There is quite a number of studies published that has involved WETCORR measurements. One reason for conducting such measurements is that the ISO 9223 standard (5) is insufficient in describing the actual TOW as experienced by an arbitrary building surface. The discrepancies between the two estimates depend on various factors of which the most important will be exemplified in the following.

\section{Effects of deposition}

The deposition of pollutants of various types greatly affects the response of surface moisture sensors, as have been noted in (32-36). It is also quite obvious 
Service Life Prediction Methodology and Metrologies, ACS Symposium Series 805, Jonathan W Martin and David R. Bauer, Eds., American Chemical Society, 2002, pp 23-36.

that exposure positions sheltered from rain are more severely affected by degradation than open ones, particularly after longer exposures when sufficient amounts of aggressive species have accumulated. In order to illustrate the effects of salt deposition on TOW for sheltered exposures, some feature results extracted from Norberg et al (36) will be discussed below.

The results were recorded in January 1996 at the Water Board site at Flinders, Victoria, Australia. This site is situated a few kilometres from the sea (Bass Strait) and the average chloride deposition rate is of the order of $30 \mathrm{mg} / \mathrm{m}^{2}$ day (37). Duplicate WETCORR sensors of the most recent design, as depicted in Figure 2, were employed. The hourly average of the current for the whole month was plotted against the surface $\mathrm{RH}\left(\mathrm{RH}_{\text {sur }}\right)$. This variable was derived from the assumption that the vapour concentration close to the surface is the same as that found in the bulk air, i.e., $\mathrm{RH}_{\text {sur }} \cdot v_{s}\left(\mathrm{~T}_{\text {sur }}\right)=\mathrm{RH}_{\text {air }} \cdot v_{s}\left(\mathrm{~T}_{\text {air }}\right)$, where $v_{\mathrm{s}}$ is the saturation vapour concentration depending mainly on the temperature $\mathrm{T}$.

The data obtained under the shelter resulted in a swarm of points that were surprisingly well kept together, giving the impression that under these conditions the WETCORR sensor acted very much like a relative humidity sensor, see Fig-

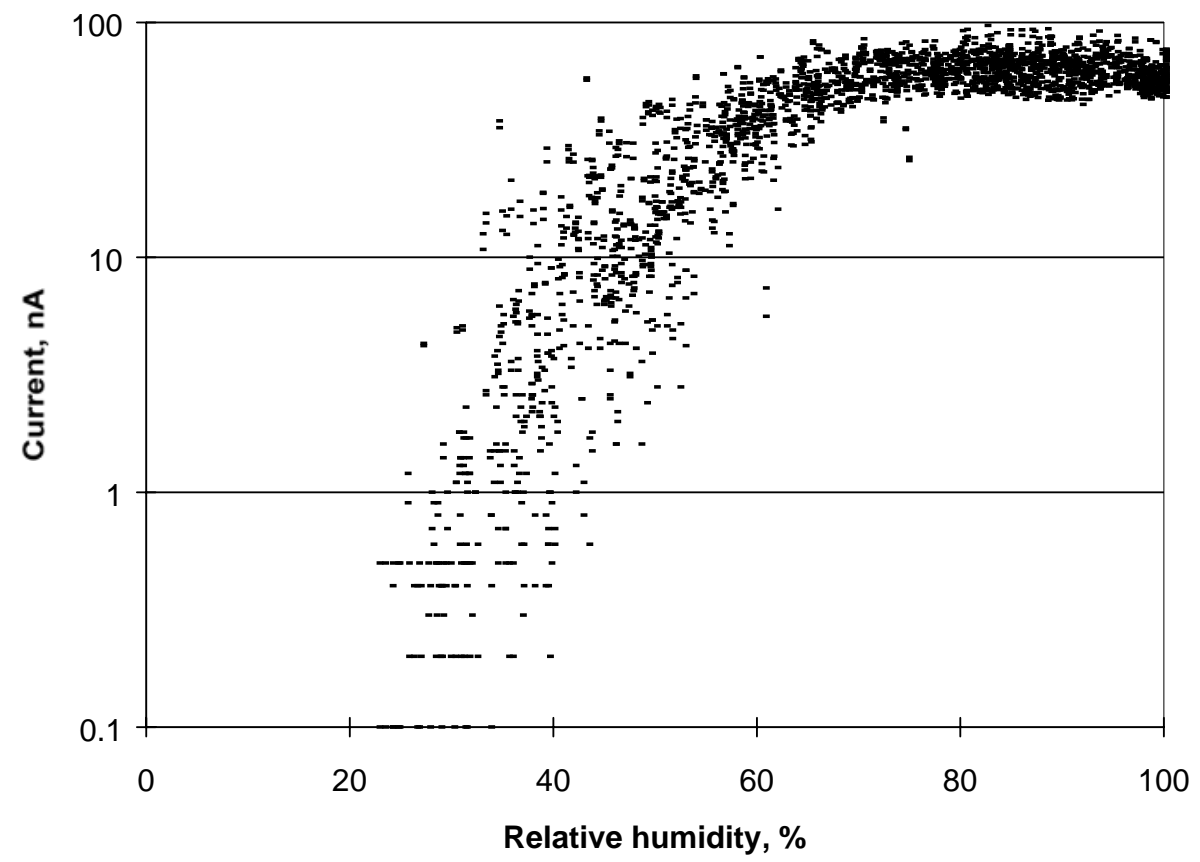

ure 5.

Figure 5. WETCORR current vs surface $R H$ for sheltered exposure at a marine site during one month.

There seems to exist a limit around 30\% RH below which the conductivity of the film becomes very low. This limit, and particularly the shape of the curve in Figure 5, can be understood from the hygroscopic properties of seawater relative to its composition and moisture content (31). Below approximately 33\% the hydrate of one of the principal constituents of sea water besides $\mathrm{NaCl}$, namely $\mathrm{MgCl}_{2}$, will completely dry out and no longer conduct electric current. Since, in this case, rain and dew have little, if any, effect on the result, the current is di- 


\section{Service Life Prediction Methodology and Metrologies, ACS Symposium Series 805, Jonathan W Martin and David R. Bauer, Eds., American Chemical Society, 2002, pp 23-36.}

rectly related to the actual moisture content of the salt film, as determined by the surface RH.

The corresponding results obtained in the open (31) were quite scattered because the current not only derived from the conductivity of the salt film, as determined by its hygroscopicity, but also from episodes of dew and rain. The rain tended to wash off most of the salt at times and as a result the sensors temporarily resumed to the original, lower sensitivity.

\section{Effects of temperature differences and radiation conditions}

It is clear that surface temperature relative to ambient is a very important parameter in determining TOW. To illustrate this, further examples of the data from the Water Board site will be given in the following.

Figure 6 shows the current as a function of the temperature difference between the air and the surface for duplicate sensors kept under the specially designed glass shelter. As is obvious, the current was always at its maximum as soon as the surface temperature dropped to below that of the ambient air, even though the difference was not greater than $1^{\circ} \mathrm{C}$. It should be noted that the WETCORR data appearing in Figures 5 and 6 are the same.

In the open, undercooling was more pronounced and frequent (31). However, since rain and dew sometimes washed the sensors in the open the sensitivity of the sensors to variations in RH was less. Consequently, the WETCORR current was comparatively low even when the surface temperature was below the ambient.

\section{Time of wetness}

When evaluating the current-time data obtained with the WETCORR equipment, a current criterion is normally chosen in order to estimate TOW. Typically, TOW is based on the time for which the average current across the sensor grid exceeds, say, 10 or $30 \mathrm{nA}$. The obtained TOW should ideally reflect the time when significant corrosion or degradation in general, takes place on a material surface being exposed to the same environment as the WETCORR sensor. From experience it may be stated that TOW is not as much a function of the amount of moisture deposited as it is of the conductivity of the moisture film. Recently, Elvedal et al (38) defined a critical current of $10 \mathrm{nA}$ that should correspond to a substantial water film $(\sim 3 \mu \mathrm{m})$ on the sensor surface. This evaluation was made in a fairly mild environment corresponding to corrosivity category C1 according to ISO 9223 (5). Should the same criterion be applied 


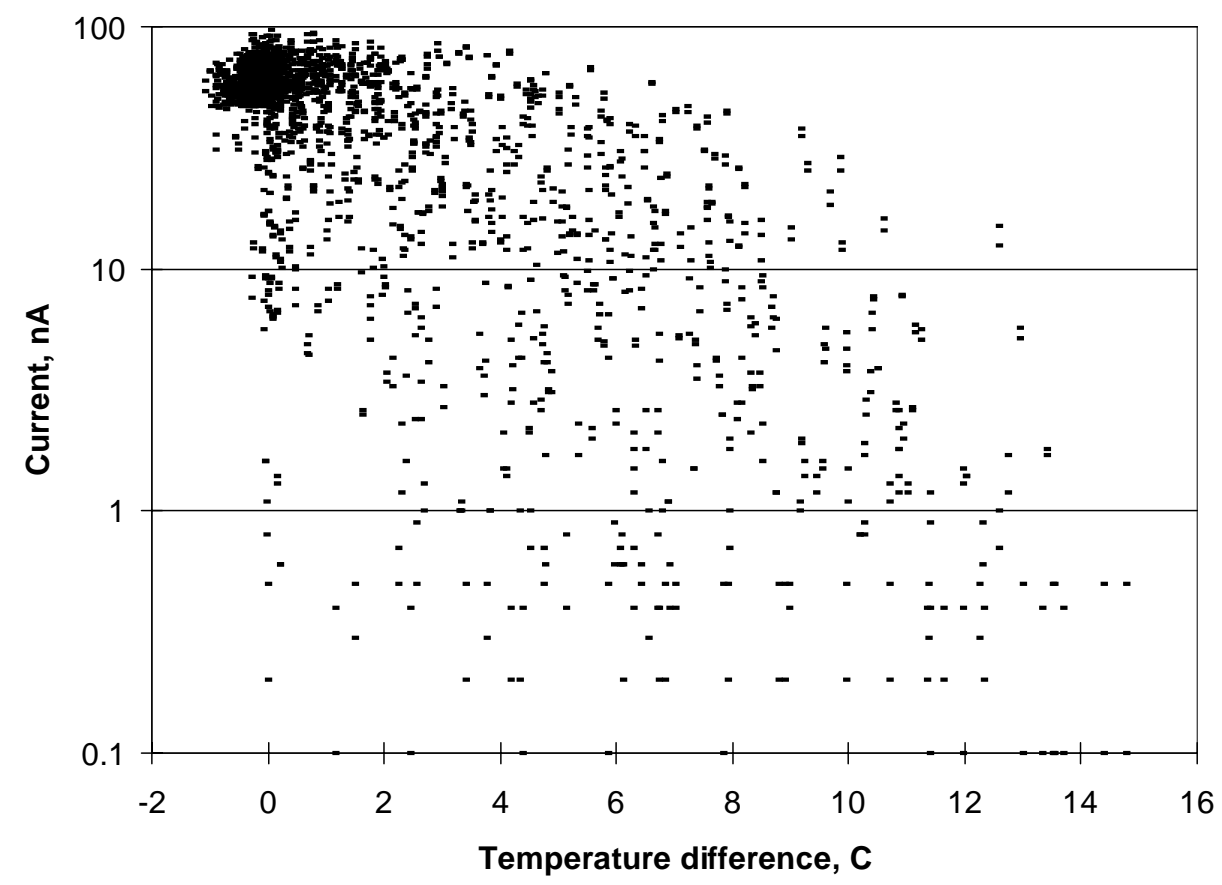

Figure 6. WETCORR current vs temperature difference between ambient air and surface for sheltered exposure at a marine site during one month.

to measurements in coastal or industrial areas, the deposition of salt and pollutants would considerably increase the conductivity and, as a consequence, the same current would be obtained for a much lower amount of surface moisture. In other words, the relation between the current and the thickness of the moisture film cannot be stated without taking the electrolytic conductivity into consideration. Presumably, there is also a better correlation between corrosivity and conductivity than between corrosivity and moisture-film thickness, particularly for natural environments.

So far, all estimates of TOW, whether made with galvanic or electrolytic cells, have been based on arbitrary criteria. This dilemma has since long been recognised by Mansfeld et al (17) and is also explicitly expressed in the ISO 9223 standard (5). In order to get around this problem a more generalised TOW concept can be introduced. This requires the use of inert electrolytic cells and a modified measuring technique.

\section{New definition of TOW}

The basic idea is to consider the measurement of surface moisture and TOW simply as a measurement of electrolytic conductivity. This is not a major deviation from the present situation but rather an adaptation to what is actually the case. For the sake of conformity this modification may be called TOC, time of conduction, or in the transferred sense for the case of atmospheric corrosion of metals, time of corrosion. 


\section{Service Life Prediction Methodology and Metrologies, ACS Symposium Series 805, Jonathan W Martin and David R. Bauer, Eds., American Chemical Society, 2002, pp 23-36.}

As shown in a preceding section on "Sensor characteristics", the response of the WETCORR sensor to the applied voltage can give information about the electrolytic conductivity and the nature of the electrode/electrolyte interface. The use of an inert sensor, such as the $\mathrm{Au} / \mathrm{Au}$ sensor in the present study, implies that the electrodes involved will not significantly be influenced by corrosion. In addition, by eliminating the impedance effects of the polarised interface, the measurement of the cell resistance will be equivalent to a conventional measurement of the electrolytic conductivity. The impedance associated with the electrode/electrolyte interface may be eliminated by AC excitation of typically a few $\mathrm{kHz}$ or by $\mathrm{DC}$ polarisation during only a few milliseconds, including reversal of the polarity. In analogy with conventional measurements of conductivity, different cell geometries can be used and still be possible to compare via the cell constant. For a given geometry the cell constant constitutes the link between resistance and resistivity or their reciprocals, conductance and conductivity. In this way, a universal criterion for the limiting conductivity above which the sensor should be considered wet may be selected.

Such a criterion remains to be agreed upon but should, most likely, be related to typical conductivities found for precipitation and dew in relatively unpolluted environments. Thus, the time of conduction, TOC, may be defined as the length of time when the electrolytic conductivity is greater than $x \mu S / \mathrm{cm}$, as measured on the surface of an inert electrolytic cell in thermal contact with the substrate material.

\section{How to make use of TOW/TOC}

TOW or TOC should not be considered as variables in the traditional sense. Since these entities are derived from variables via selected criteria they are rather delimiters or discriminators. Consequently, they should not be explicitly utilised in mathematical expressions such as dose-response functions of the type originally proposed by Guttman and Sereda (39). Instead TOW/TOC should be used to discriminate wet and dry periods from each other, i.e. to determine when the "wet" and "dry" model, respectively, should be used for calculating the extent of degradation (31). This procedure is most obvious for metals but should also be applicable to non-metallic materials.

\section{Conclusions}

The WETCORR technique has been developed into a versatile tool for making microclimate measurements in the built environment. The present version of the equipment can accommodate up to 64 surface moisture grids and just as many temperature sensors. The latest version of sensor is considered very suitable to estimating surface moisture loads and times and simultaneously to give a reasonably correct value of the surface temperature. The corrosion resistance of the combined moisture and temperature sensor has also improved considerably compared with previous versions.

The function of the Au/Au-type sensor under controlled conditions in the laboratory as well as in the field studies has shown very good reproducibility. A simple equivalent electric circuit that helps explaining the transient character of 


\section{Service Life Prediction Methodology and Metrologies, ACS Symposium Series 805, Jonathan W Martin and David R. Bauer, Eds., American Chemical Society, 2002, pp 23-36.}

the measured WETCORR current on excitation can describe the working principle of the moisture sensor. This transient is attributed to the electrolytic conductance of the moisture film on the surface of the sensor grid. The asymptotic DC current, on the other hand, is the result also of electrode/electrolyte reactions. Measurement of moisture conditions and TOW should most likely be associated with the conductance of the electrolyte. To improve the sensitivity of the method with regard to moisture detection, AC excitation or short pulses of DC may be used to eliminate the capacitive properties of the cell.

There are numerous examples of the limitations of the ISO 9223 standard for estimating TOW. First, corrosion is not limited by temperatures below $0^{\circ} \mathrm{C}$. Secondly, in most exposure environments, deposition of pollutants and salt will generally lower the RH above which wetting of the surface occurs due to the hygroscopicity of the deposits. For marine environments it is shown that the surface film remains conducting down to a surface $\mathrm{RH}$ of around $30 \%$. This phenomenon is most pronounced for rain sheltered positions. Thirdly, radiation exchange between surfaces and the environment is not considered. Differences in temperature between a surface and the surrounding air may be considerable and cause both evaporation and condensation.

A generalised definition of TOW is proposed which takes into account the conductivity of the moisture film rather than its thickness. Under the assumption that significant degradation by corrosion or any other moisture related mechanism cannot occur below a certain conductivity, a universal criterion for TOW can be defined. This modified TOW is called time of conduction or time of corrosion, TOC, and is defined as the length of time when the electrolytic conductivity is greater than $\mathrm{x} \mu \mathrm{S} / \mathrm{cm}$, as measured by an inert moisture sensor in thermal contact with a substrate material. The exact value of the limiting conductivity remains to be agreed upon. In compliance with conventional measurements of conductivity, any cell can be calibrated by determining the cell constant for the electrode configuration in a standard electrolyte.

The adoption of the TOC concept makes possible a more strict separation of time into "wet" and "dry" periods. In other words, TOC can be used to discriminate between periods when different dose-response relations should be applied to describing the degradation. This also implies that modelling of dose-response relations would not have to include TOW in the actual models.

\section{Literature Cited}

1. Vernon, W H J, Laboratory Study of the Atmospheric Corrosion of Metals, Transactions of the Faraday Society, Vol 31, 1935, pp 1678-1686.

2. Tomashov, N D, Atmospheric Corrosion of Metals, Theory of Corrosion and Protection of Metals, Chapter XIV, MacMillan, New York, 1966, pp 367398.

3. Mansfeld, F, Evaluation of Electrochemical Techniques for Monitoring of Atmospheric Corrosion Phenomena, Electrochemical Corrosion Testing, ASTM STP 727, 1981, pp 215-237.

4. Mansfeld, F, Electrochemical Methods for Atmospheric Corrosion Studies, Atmospheric Corrosion, The Electrochemical Society, 1982, pp 139-160.

5. ISO 9223, Corrosion of Metals and Alloys, Classification of Corrosivity Categories of Atmospheres, 1992. 
Service Life Prediction Methodology and Metrologies, ACS

Symposium Series 805, Jonathan W Martin and David R. Bauer, Eds., American Chemical Society, 2002, pp 23-36.

6. Sereda, P J, Croll, S G and Slade, H F, Measurement of the Time-of-Wetness by Moisture Sensors and Their Calibration, Atmospheric Corrosion of Metals, ASTM STP 767, 1982, pp 267-285.

7. Hechler, J J, Boulanger, J, Noël, D, Dufresne, R and Pinon, C, A Study of Large Sets of ASTM G 84 Time-of-Wetness Sensor, Corrosion Testing and Evaluation:Silver Anniversary Volume, ASTM STP 1000, 1990, pp 260-278.

8. King, G A and Duncan, J R, Some Apparent Limitations in Using the ISO Atmospheric Corrosivity Categories, Corrosion \& Materials, Vol 23, No 1, 1998, pp 8-14 \& 22-24.

9. Grossman, P R, Investigation of Atmospheric Exposure Factors that Determine Time-of-Wetness of Outdoor Structures, Atmospheric Factors Affecting the Corrosion of Engineering Materials, ASTM STP 646, 1978, pp 5-16.

10. Dean, S W and Reiser, D B, Time of Wetness and Dew Formation: A Model of Atmospheric Heat Transfer, Atmospheric Corrosion, ASTM STP 1239, 1994, pp 3-10.

11. Tomashov, N D, Berukshtis, G K and Lokotilov, A A, Zavodskaja Laboratorija, 22, (3), 1956, pp 345-349.

12. Sereda, P J, Measurement of Surface Moisture, A Progress Report, ASTM Bulletin No 228, Feb 1958, pp 53-55.

13. Sereda, P J, Measurement of Surface Moisture, Second Progress Report, ASTM Bulletin No 258, May 1959, pp 61-63.

14. ASTM G84-84, Standard Practice for Measurement of Time-of-Wetness on Surfaces Exposed to Wetting Conditions as in Atmospheric Corrosion Testing, ASTM, 1984.

15. Kucera, V and Mattsson, E, Electrochemical Technique for Determination of the Instantaneous Rate of Atmospheric Corrosion, Corrosion in Natural Environments, ASTM STP 558, 1974, pp 239-260.

16. Mansfeld, F and Tsai, S, Laboratory Studies of Atmospheric Corrosion - I. Weight Loss and Electrochemical Measurements, Corrosion Science, Vol 20, 1980, pp 853-872.

17. Mansfeld, F, Tsai, S, Jeanjaquet, S, Meyer, E, Fertig, K and Ogden, C, Reproducibility of Electrochemical Measurements of Atmospheric Corrosion Phenomena, Atmospheric Corrosion of Metals, ASTM STP 767, 1982, pp 309-338.

18. Kucera, V and Gullman, J, Practical Experience with an Electrochemical Technique for Atmospheric Corrosion Monitoring, Electrochemical Corrosion Testing, ASTM STP 727, 1981, pp 238-255.

19. Mansfeld, F, Monitoring of Atmospheric Corrosion Phenomena with Electrochemical Sensors, J Electrochem Soc, Vol 135, No 6, 1987, pp 13541358.

20. Haagenrud, S, Kucera, V and Gullman, J, Atmospheric Corrosion Testing with Electrolytic Cells in Norway and Sweden, Atmospheric Corrosion, The Electrochemical Society, 1982, pp 669-693.

21. Haagenrud, S E, Henriksen, J F, Danielsen, T and Rode, A, An Electrochemical Technique for Measurement of Time of Wetness, Proc 3rd Int Conf on Durability of Building Materials and Components, Espoo, 12-15 Aug 1984, pp 384-401.

22. Haagenrud, S E, Henriksen, J F and Wyzisk, Electrochemical Characteristics of the NILU/SCI Atmospheric Corrosion Monitor, Corrosion 85, NACE, Boston, 25-29 March, 1985, Paper 83. 
Service Life Prediction Methodology and Metrologies, ACS

Symposium Series 805, Jonathan W Martin and David R. Bauer, Eds., American Chemical Society, 2002, pp 23-36.

23. Haagenrud, S, Henriksen, J and Svennerstedt, B, Våttidsmålinger på treplater - Prøvestudie med NILU WETCORR-metoden (Time of wetness measurements on wood - Pilot study of the NILU WETCORR method), NILU OR 17/85, 1985, (In Norwegian).

24. Svennerstedt, B, Time of Wetness Measurements in the Nordic Countries, Proc 4th Int Conf on Durability of Building Materials and Components, Singapore, 4-8 Nov 1987, pp 864-869.

25. Svennerstedt, B, Ytfukt på fasadmaterial (Surface moisture on facade materials), The National Swedish Institute for Building Research, Research Report $T N: 16,1989$, (In Swedish).

26. Lindberg, B, Mätning av våttid på målade byggnadsmaterial (Measurement of TOW on painted surfaces of building materials), Scandinavian Paint and Printing Ink Research Institute, NIF-Report T 2-88 M, 1988, (In Swedish).

27. Yamasaki, R S, Characterization of Wet and Dry Periods of Plastic Surfaces during Outdoor Exposure, Durability of Building Materials, Vol 2, No 2, 1984, pp 155-169.

28. Norberg, P, Evaluation of a New Surface Moisture Monitoring System, Proc 6th Int Conf on Durability of Building Materials and Components, Omiya, Japan, 26-29 Oct 1993, Paper 3.7, pp 637-646.

29. Norberg, P, Monitoring of Surface Moisture by Miniature Moisture Sensors, Proc 5th Int Conf on Durability of Building Materials and Components, Brighton, UK, 7-9 Nov 1990, pp 539-550.

30. Metals Handbook, Ninth Edition, Volume 13, Corrosion, ASM International, 1987, pp 212-228.

31. Norberg, P, Ph.D. thesis, Centre for Built Environment, Royal Institute of Technology, Gävle, Sweden, 1998.

32. Norberg, P, Sjöström, C, Kucera, V and Rendahl, B, Microenvironment Measurements and Materials Degradation at the Royal Palace in Stockholm, Proc 6th Int Conf on Durability of Building Materials and Components, Omiya, Japan, 26-29 Oct 1993, Paper 3.2, pp 589-597.

33. Norberg, P, King, G and O’Brien, D, Corrosivity and Microclimate Measurements in Open and Sheltered Marine Environments, Proc 7th Int Conf on Durability of Building Materials and Components, Stockholm, Sweden, 1923 May 1996, Vol 1, Paper 18, pp 180-190.

34. Cole, I S, Norberg, P and Ganther, W D, Environmental Factors Promoting Corrosion in Building Microclimates, 13th International Corrosion Congress, Melbourne, Australia, 25-29 Nov 1996, Paper 410.

35. Rendahl, B, Kucera V, Norberg, P and Sjöström, C, Våt- och torrdeponering av försurande luftföroreningar. Inverkan på byggnadsmaterial. (Wet and dry deposition of acidifying air pollutants. Effect on building materials), KIReport 1995:3, Swedish Corrosion Institute, (In Swedish).

36. Norberg, P, King, G A, O’Brien, D J and Sherman, N, MIME Extension: A Project to Measure the Short Term Corrosion Rates of Steel, Zinc and Coated Steels and Correlate with Climatic Parameters and Time-of-Wetness, CSIRO DBCE Doc. 96/23 (M), Mar 1996.

37. Norberg, P, King, G and O’Brien, D, Corrosivity Studies and Microclimate Measurements in Marine Environments. ACA Annual Conference, Corrosion \& Prevention 95, Perth, Australia, 12-16 Nov 1995, Paper 36.

38. Elvedal, U, Henriksen, J F and Haagenrud, S, Project Deliverable No. $7.1-$ Final Report WP2: Calibration of WETCORR Sensors in Field and Labora- 
Service Life Prediction Methodology and Metrologies, ACS Symposium Series 805, Jonathan W Martin and David R. Bauer, Eds., American Chemical Society, 2002, pp 23-36.

tory, EU-project ENV4-CT95-0110 Wood-Assess, Wood-Assess Document No:WP2/Del7.1/NILU/1998.08.15, 1998, (Confidential).

39. Guttman, H and Sereda, P J, Measurement of Atmospheric Factors Affecting the Corrosion of Metals, "Metal Corrosion in the Atmosphere", ASTM STP 435, 1968, pp 326-359. 